doi: $10.19090 /$ i.2019.30.272-293

UDC: $272-726.1$ Stepinac A.

ISTRAŽIVANJA

JOURNAL OF HISTORICAL RESEARCHES

30 (2019)
ORIGINAL SCIENTIFIC PAPER

Received: 10 August 2019

Accepted: 13 September 2019

\author{
MILAN KOLJANIN \\ Institute of Contemporary History, Belgrade \\ mbkoljanin@gmail.com
}

DRAGICA KOLJANIN

University of Novi Sad, Faculty of Philosophy

Department of History

dragica.koljanin@ff.uns.ac.rs

\title{
ARCHBISHOP STEPINAC, THE INDEPENDENT STATE OF CROATIA AND WESTERN ALLIES
}

\begin{abstract}
There are various doubts and ambiguities regarding the dispatch of the memorandum by the Government of the Independent State of Croatia (ISC) to the Western Allies asking for military intervention in early May 1945, giving rise to different interpretations in historiography. These varying interpretations are related to the circumstances of the dispatch of the memorandum, its text, the actions of prominent representatives of the Ustasha government, relations between the new Yugoslav authorities and Western allies, especially the British and the role of Archbishop Stepinac and the Holy See in the ISC. In order to understand the memorandum, it is necessary to consider the most important political and military circumstances at the end of World War II in Yugoslavia, especially the politics of the new Yugoslavia and the Western powers, primarily the British. The representatives of the Holy See in the ISC and the Archbishop of Zagreb, Alojzije Stepinac, played an important role in efforts to preserve the Ustasha state. This paper was written based on unpublished and published archival sources and relevant historiographical literature.
\end{abstract}

Keywords: World War II, Yugoslavia, the Ustasha government, memorandum, Western Allies, Archbishop Stepinac, Holy See.

\section{The Zagreb trial and the Ustasha government morandum}

$\mathrm{D}$ uring the trial of the Archbishop of Zagreb, Dr. Alojzije Stepinac, Erich Lisak and other members of the state apparatus of the Independent State of Croatia (ISC) and the Roman Catholic Church in Zagreb in October 1946, the court sought to shed light on the role of the accused during the last days of the Ustasha state. At the time, there was talk of a memorandum from the ISC government sent to the command of the Western Allies in Italy asking for military intervention. During the hearing of the accused Lisak, Public Prosecutor Jakov Blažević asked about the preparations of the highest Ustasha 
officials for leaving the country. Lisak replied that there were no specific preparations underway unless "the departure of Minister Vrančić by plane to Italy"1 was considered as such. The public prosecutor did not continue the inquiry on the matter, noting that Vrančić travelled "for a different reason". ${ }^{2}$ During the hearing of the accused Archbishop Stepinac regarding the attempt to preserve the ISC and his role in it, the presiding trial judge Žarko Vimpulšek asked about Poglavnik (State Chief) Pavelić's offer to the Archbishop to take power. Stepinac replied that it was a kind of regency, but that he had refused and suggested to Maček that he take power "as a political representative of the Croats". The presiding judge then asked the archbishop if he had been told by the authorities that they had "caught on to a connection with the allies", with the archbishop replying that he had not. The following questions to Stepinac investigated whether he heard "of those aviators who left with the memorandum" and whether he was aware of the contents of the memorandum. The answer to both questions was negative. ${ }^{3}$

More details about the memorandum were revealed during the hearing of the Minister of Foreign Affairs of the ISC, Dr. Mehmed Alajbegović. When asked by the presiding judge to say what he knew about the memorandum the Ustashas had prepared for Western allies in April 1945, Alajbegović replied that its drafting had been entrusted to Prime Minister Nikola Mandić and Ivo Bogdan, head of state propaganda. The purpose of the memorandum was to maintain the ISC as a "separate state entity", whereas the dispatch of the document was entrusted to General Ante Moškov. Alajbegović added that he thought that "Minister Vrančić took one copy of the memorandum abroad". ${ }^{4}$ At a later point in the trial, the prosecutor stated that the purpose of the memorandum was to provoke foreign intervention. ${ }^{5}$

During the court process in October 1946 the memorandum was not presented to the accused or to the public, though it was partly published in the newspapers and soon after in the book Trial of Lisak, Stepinac, Šalic and associates, Ustasha-Crusader criminals and their helpers (Suđenje Lisaku, Stepincu, Šaliću I družini, ustaško-križarskim zločincima I njihovim pomagačima). A note from the book's editor stated that Vrančić travelled by plane to Italy "to hand over the memorandum to the Anglo-American command, stating, among other things". Following the note, the title of the document was given: "Memorandum" and then the text itself, but without any indicators pointing to the missing parts of the text. The document was based on a quasi-historical argumentation and the need for the existence of the independent Greater Croatia. It was emphasized that the ISC, with all its state attributes, had been in existence for four years. As a "guardian of the eastern seaboard of the Adriatic Sea" it could have been of great benefit to the United Kingdom and, owing to Croatian Muslims, it could have been part of the "Mediterranean-Balkan bloc of non-Bolshevik forces", along with Turkey, Greece and Albania. It was pointed out that this was not a fight "for any kind of political ideology, least of all a fascist one" and that this was "purely a Croatian defensive war". The memorandum continually pointed out the existence of the Greater Croatia (ISC), but at the same time emphasized its readiness for border changes,

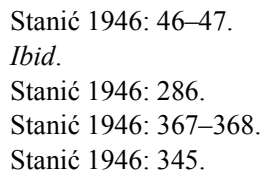


both in the east and in the west, with the arbitration of Western powers. The demand was also put forth for the Croatian people to be given the right to self-determination "on the basis of the existing state of facts in the Croatian state".

A key part of the memorandum included the following: "The Croatian State Government wishes and asks that your military mission be sent to Croatia as soon as possible, so that you can gain insight into the facts. At the same time, we kindly ask that your army come to our state territory to alleviate this serious and devastating situation. This puts the Croatian people in their own country under your powerful protection". In addition to this passage, the editor stated in parenthesis: "Underlined by the author of the memorandum". In the end, it was stated that the memorandum was signed by "Dr. Nikola Mandić, Prime Minister of the Ustasha Government of the so-called ISC". ${ }^{6}$

Based on the information given in October 1946 at the trial in Zagreb, published in the press at the time of the events, and ultimately in the book, it could be concluded that the memorandum was approved by the ISC government, translated into English and that Minister Vrančić "travelled by plane to Italy" with the purpose of handing it over to the Anglo-American Command. The aviators "who left with the memorandum" were also mentioned. When it came to the role of Archbishop Stepinac, it appeared that Pavelić offered him to take over power, but Stepinac did not accept it. Instead, the archbishop suggested that Vlatko Maček should take this position, since he, as a political leader, was a suitable figure. Although the archbishop denied that he went to Maček at the behest of Pavelić, this indeed took place with the consent of the Ustasha leader, who made the meeting possible. ${ }^{7}$ In relation to the ISC government memorandum, the public prosecutor was satisfied with the archbishop's response that he was not aware of the memorandum having been sent to Western allies or its contents.

\section{Two memoranda}

More light on the issue of sending the memorandum of the ISC government was cast by the recollection of Vjekoslav Vrančić published in 1953, who was the Minister of Crafts, Transport and Trade in the ISC government and an Ustasha Major. ${ }^{8}$ His recollection is further interesting because it is the only source that mentions the role of the German factor. Vrančić stated that the text of the memorandum ("Memorial") was adopted at the session of the government, translated into English and signed by all members of the government. It was agreed that one copy of the memorandum would be taken to the Allied Force Headquarters in Italy by two US pilots, prisoners of war, who agreed to do so. The second copy of the memorandum was to be taken to Western allies by Vrančić himself, who was authorized to offer them the surrender of the ISC armed forces. ${ }^{9}$ A German Minister Siegfried Kasche, who was informed of this, welcomed the intentions of the Ustasha government and offered assistance. He suggested that the members of the mission flew by

\footnotetext{
Stanić 1946: 46-48.

Stanić 1946: 285-286; 346-346.

Vrančić 1953: 7.

Vrančić 1953: 24-25.
} 
plane to Klagenfurt, where he would secure the assistance of German military and civilian institutions in making sure the mission reached the Allied Force Headquarters in Italy. ${ }^{10}$ It should be noted that at that time German forces in Italy had already capitulated and that US forces had already occupied the southern part of the Great German Reich (Austria).

According to Vrančić's recollection, the Ustasha Prime Minister Nikola Mandić informed him on 5 May 1945 at about 8 AM that two American pilots had already taken the first copy of the memorandum and ordered him to prepare for the mission. Since other sources link the departure of the pilots to 4 May 1945, Vrančić's departure most likely also took place on that day. Still, it cannot be ruled out that he really left on 5 May. According to Vrančić, immediately before the plane was to take off from Zagreb, the departure of the mission was postponed after Pavelić's request that they be joined by the secretary of Abbot Marcone (Masucci), along with a young Croatian priest; subsequently, however, it was announced that the priests would not be travelling. ${ }^{11}$ After that delay, at about 2 PM, Vrančić flew to Klagenfurt, from where, the next day, on 6 May 1945, ${ }^{12}$ he continued his journey to Italy by car. Having arrived at the command of the British $8^{\text {th }}$ Army in the village of Marocco near Venice, Vrančić requested that he be sent to Caserta to the headquarters of Field Marshal Alexander. Soon after, however, he was arrested and sent to a civilian internment camp in Terni, where he was stripped of the memorandum, governmental authorization, diplomatic passport and notes. From there, he was transferred to other camps, together with the confiscated documents, as he assumed. After his escape from the Afragola camp, the aforementioned documents were left there. ${ }^{13}$

An important source related to the events in Zagreb during the last days of the ISC is the diary of Giuseppe Masucci, secretary to Abbot Giuseppe Ramiro Marcone, the Legate of the Holy See in the ISC, published in 1967 by the Ustasha emigration to Spain. ${ }^{14}$ Although Masucci did not mention the Ustasha government memorandum of 4 May 1945, his testimony indicates that he was probably informed of its preparation. Masucci noted on 2 May 1945 that he had spoken to Stepinac who "will probably travel to Rome. Everything will be decided tomorrow with the Poglavnik"15 In the next day's entry Masucci noted that he had met with Pavelić and discussed with him "ways of reaching an agreement with the English, inviting them to come to Zagreb and thus preventing communist occupation." 16 According to the entry dated 5 May 1945, Masucci once again met with Pavelić. He noted that he was to embark on a special mission that day with the aim of inviting the Allies "to come and occupy Zagreb where they would not encounter any resistance". He ended the note by remarking that his mission had suddenly been halted at the request of papal Legate Marcone. ${ }^{17}$ Vrančić's description of the departure of Masucci's mission coincides somewhat with the description of Masucci himself, and one might conclude that his recollection of this

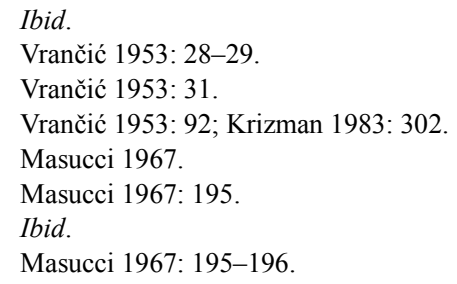


part of the events is plausible. However, other sources should also be consulted in order to resolve the timing of Vrančić's departure. In any case, from his recollection it could be unequivocally established that two memoranda were sent from Zagreb to the Allies in Italy. One was carried by American pilots and the other by Vrančić. His copy of the memorandum later disappeared in one of the camps in Italy in which he was interned by British authorities.

\section{Interpretations and new sources}

The issue of sending the memorandum written by the Ustasha government in May 1945 had various interpretations in historiography and historiographical papers. Milan Basta conveys the text of the memorandum published in 1946, stating that it was taken to the Allies by Ustasha minister Vjekoslav Vrančić. ${ }^{18}$ He claims that Vrančić brought along with him five US pilots, prisoners of war, but that on his arrival in Italy he was captured by an American colonel with the explanation that Tito was their ally. ${ }^{19}$ In the first comprehensive historiographical study of the Ustashas and their state published in 1977, Fikreta Jelić-Butić states that the Ustasha leadership, in order to save the ISC, attempted to get in touch with certain American or British factors and request their intervention. She points out that the main attention and importance was given to the attempt to deliver the memorandum of the ISC government to the Allied Force Headquarters in the Mediterranean. She claims that the memorandum was to be handed over by Minister Vrančić, who set off on a special plane, accompanied by three captured English officers. After presenting the contents of the memorandum, the author concludes that this action, as well as the previous ones, did not have any effect on those whom it addressed. ${ }^{20}$ The author did not use Vrančić's recollection and, instead, relied on the testimony of Mehmed Alajbegović at the trial of Archbishop Stepinac and others, and on published materials from 1946 in connection with the memorandum. ${ }^{21}$ According to the author, there existed only one mission the goal of which was to deliver the memorandum. It remains unclear how the Ustasha government, via Minister Vrančić, attempted to hand over the memorandum to Field Marshal Harold Alexander, so that this action also "did not have any particular effect" on those addressed by the ISC government. This is an obvious contradiction, since, unless a memorandum was not received at the Allied command in Caserta, one cannot even speak of the effect that it had or could have had.

A major step forward regarding the ISC government memorandum was the publication of documents by the British Foreign Office in 1980. Jerome (Jere) Jareb and Ivo Omrčanin published six documents related to the ISC government memorandum addressed to Field Marshal Alexander, including the text of the memorandum. The authors assert that the memorandum had no influence on the Allied decisions at the time, but that it was of historical significance because it was "the last significant statement made by the Croatian

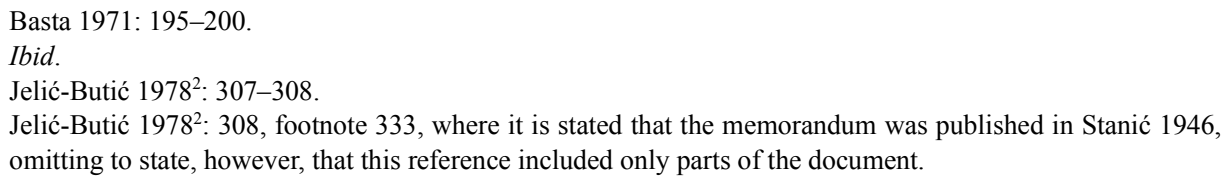


war regime". ${ }^{22}$ The documents were published in a chronological order of their arrival at the Foreign Office in London. It can be seen immediately that the communication of the London Ministry with the diplomatic representatives in Italy and Yugoslavia was delayed in relation to the actual communication between the representatives. It appeared that the problems raised by the memorandum were solved at the level of British diplomatic and military representatives in Italy and Yugoslavia, with which the Foreign Office itself subsequently agreed.

The first news of the delivery of the ISC government's memorandum came on 4 May 1945 from Harold MacMillan, Resident Minister for the Central Mediterranean in Caserta. At the request of Field Marshal Alexander, MacMillan sent a telegram to the British Ambassador to Belgrade, Ralph Stevenson and the London Foreign Office at 6.29 PM that day. However, the telegram did not arrive in London, so that, a week later, the Foreign Office requested that MacMillan send it one more time. ${ }^{23}$ The British representatives in Caserta concluded that this event was of the utmost importance and required a swift response. MacMillan's telegram to Stevenson was marked as top-secret - the authorized recipient eyes only. The telegram stated that a German aircraft piloted by a Croatian officer carrying three British prisoners of war arrived from Zagreb at one of Zara (Zadar) airfields that morning. It further stated that this party carried documents conveying a request for Allied military intervention for the benefit of the Croatian government and its people, after which 18 signatories were listed. MacMillan asked Stevenson to immediately inform Marshal Tito of the event and of their position, according to which the British would "refuse to enter into any negotiations of any kind with the aforementioned party". He suggested that the Croatian officer be detained for some time, whereas the British officers would be repatriated. As a personal piece of information intended for Stevenson, MacMillan stated that one of the British officers had given his word, but that "for military reasons, we do not propose that an airplane or officer be returned". Given that he expected Tito to demand that the Croatian officer be handed over to Yugoslavs, MacMillan suggested that a formal request be made to him, which would then be handed over to Field Marshal Alexander. ${ }^{24}$

On the following day, 5 May 1945, Ambassador Stevenson briefed MacMillan in Caserta and the Ministry in London about the steps taken. It was only from this telegram that London learned of the memorandum and the steps taken. Stevenson reported that he had conveyed MacMillan's message to Marshal Tito, including the list of signatories to the memorandum. Tito thanked him and pointed out that some of the signatories had already been sentenced to death by the pre-war Yugoslav government as Pavelićs terrorist followers. Following this, the Yugoslav Prime Minister handed over a note from his government to Ambassador Stevenson. The note stated that the Yugoslav Ministry of Foreign Affairs was aware that on 4 May 1944 two Ustasha planes touched down at the Škabrnje airport in the Yugoslav territory. Ustasha Second Lieutenant Vitomir Dubaj was in one of them. It was pointed out that both planes were considered Yugoslav spoils-of-war, as they had landed on Yugoslav territory under Yugoslav command, and that Dubaj was "a

\footnotetext{
Jareb, Omrčanin 1980: 120-143.

Jareb, Omrčanin 1980: 122.

Jareb, Omrčanin 1980: 124-126.
} 
rebel" who was to be surrendered to Yugoslav authorities. After citing the text of the note, Stevenson remarked that the message was also addressed to Field Marshal Alexander, stating that Alexander would not mind handing over the two planes that were at the time in Škabrnje with the "rescue party". ${ }^{25} \mathrm{He}$ felt that there was no reason to refuse the handover of the Ustasha officer to the Yugoslavs. A subsequent comment made on 10 May 1945 by the Foreign Office regarding this document was that it could be left to Caserta and Belgrade to deal with the case, requesting only, however, to be notified of all the facts. ${ }^{26}$

The proposals of the British ambassador to Belgrade were accepted in Caserta, on which MacMillan informed Stevenson and the Foreign Office on 7 May 1945. MacMillan stated that he and Field Marshal Alexander had agreed to surrender the two planes and the Croatian officer to the Yugoslav authorities and to release British personnel from any promise they may have given. ${ }^{27}$ Over the following days, during the correspondence between the Foreign Office, Stevenson and MacMillan, as well as within the Ministry itself, it was ascertained that the airport and the village of Škabrnje were located $18 \mathrm{~km}$ east of Zara (Zadar) "in an indisputably Yugoslav territory", and not in the Italian territory to which Tito made claims. Basic information on the signatories of the memorandum was also established. The original document of the ISC government memorandum arrived to Foreign Secretary Anthony Eden from Caserta on 18 May $1945 .{ }^{28}$ The letter of the memorandum was appended by a letter from Prime Minister Nikola Mandić to the Allied Force Headquarters for the Mediterranean. ${ }^{29}$ In the letter Mandić addressed the Allied command "with the preliminary consent of our state Chief", i.e. Pavelić. Mandić urged the Allied Force Headquarters to send a military mission to Zagreb "as soon as possible", appealing for the intervention of its military forces and seeking direct contact with the Allied command. In the end, he stated that the "petition" that followed expounded the reasons for it.

In the editors' preface to the published collection of Foreign Office documents, basic facts about the creation of the memorandum are stated, based on the recollections of the author of the memorandum Ivo Bogdan and the published statement of Mehmed Alajbegović. Errors in the text of the memorandum are explained by the speed at which the text was drafted, accepted and sent. Following this, the editors reconstructed the timeline of events. On 2 May 1945, the ISC government agreed to send a memorandum to the Allies. This was entrusted to Ivo Bogdan, who was assisted by Edo Bulat and Alajbegović himself. The document was finalized on 3 May in the evening, following which it was certified by the government's political committee and Pavelić himself. The Ustasha leader dictated a cover letter signed by Prime Minister Mandić and ordered the memorandum to be translated into English. Early in the morning of 4 May the government met and all its members signed

25 Jareb, Omrčanin 1980: 121-122. This telegram was published in the collection of documents by Biber 1981: 525526. Footnote 686 refers to MacMillan's telegram which informed of "the arrival of the Ustasha plane carrying the note from the Government of ISC and instructed Stevenson to inform Marshal Tito that no negotiations were to be taken with this party". The British document misstated the date on the note of the Yugoslav government as 4 May 1944, instead of 4 May 1945. Neither Jareb/Omrčanin nor Biber commented on this.

26 Jareb, Omrčanin 1980: 122.

27 Jareb, Omrčanin 1980: 123.

Jareb, Omrčanin 1980: 122-123, 126-130.

Jareb, Omrčanin 1980: 131, 132-142. 
the memorandum, after which the plane was sent to the Allied command in Italy.

The editors of the collection of documents also addressed the issue of organizing the dispatch of the memorandum, relying on the recollections of the priest Theodor Benković, a chaplain at the prison camp in Zagreb. He said that during the last days of the war the government had arranged a meeting with war prisoners Lieutenant Rodney Woods, an Englishman, Lieutenant Edward J. Benkoski, an American, and John Gray, a Scottish officer. According to Benković, they went, along with a Croatian officer, to negotiate a Croatian surrender with the Anglo-Americans without achieving success. In a postwar statement given to J. Jareb, Benkoski stated that they had been accompanied by a Croatian officer whose name he had not remembered, stating that he had most likely been killed by Tito's partisans "when their two light aircraft were detained near Zadar" ${ }^{30}$ It is not clear how Benkoski could have learned that a Croatian (Ustasha) officer accompanying them had been killed and it is even harder to assume that the captured US pilots also knew about it. ${ }^{31}$

J. Jareb and I. Omrčanin determined that the Croatian draft of the memorandum was shortened due to the short time allotted for translation and that "the section dealing with Croatian-Serbian relations was completely omitted". They argue that it was this version of the draft that reached Yugoslav authorities in Zagreb, that it was published in newspaper reports during the process to Archbishop Stepinac, after which parts of the memorandum were published in Trial of Lisak, Stepinac, Šalic and associates. ${ }^{32}$ This is certainly true, as can be confirmed by the editors' note that the memorandum was "signed by Dr. Nikola Mandić, Prime Minister of the Ustasha Government of the so-called ISC". This certainly refers to the Croatian version, previously signed only by N. Mandić, while the final version in English was signed by all the ministers headed by Mandić. Most likely, the Yugoslav authorities found the Croatian text of the memorandum in the archives of the Ministry of Foreign Affairs of the ISC, which Minister Alajbegović had handed over to Archbishop Stepinac immediately before the withdrawal from Zagreb in May 1945. In any case, there is no mention as to where the memorandum was found and, so far, it is unknown where this copy is kept. Therefore, only the English version of the memorandum published in 1980 and its abbreviated version published in 1946 can be compared; it remains unknown whether only a "section dealing with Croatian-Serbian relations" was omitted in the English version. ${ }^{33}$ If the two texts of the memorandum are compared, it is clear that the one published in 1946 only partly refers to "Croatian-Serbian relations".

The aforementioned claim refers to the following part of the memorandum: "The defense of Croatia is, therefore, not a fight for any kind of political ideology, least of all a fascist one. It is a purely a Croatian national-defensive war. Proof of this is the fact that in the month of October - when it was believed that there would be Anglo-American landings on the Croatian coast in Dalmatia - a command was issued to Croatian military units in the area that the Croatian armed forces were to offer no resistance to the attempt of any military disembarkation or military activities by Anglo-American troops on our territory". "The

30 Jareb, Omrčanin 1980: 124, footnote 12.

31 Ibid. The testimony of the second American pilot that the Ustasha officer was shot by Yugoslav forces was published in McAdams 1980.

32 Jareb, Omrčanin 1980: 132, footnote 42.

33 Ibid. 
Croatian people are ready to settle their borders, especially in the East, on a generous basis. Today, the relations of cooperation in the fight against the common enemy already exist with the national elements of Serbia, Montenegro and Albania. The Croatian people are ready to accept arbitration of Great Britain and the United States of America in terms of defining its borders. With respect to the demarcation with Italy, we emphasize that Croatia sees in Rijeka not only its most important port, but also the exit of the Danubian countries to the Adriatic and the Mediterranean".

It can be concluded that this is an attempt to portray Croatia (ISC) as a non-fascist and supra-ideological state waging a defensive war, cooperating with "the national elements of Serbia, Montenegro and Albania", one which is ready to settle the issue of its borders by means of Anglo-American arbitration. The primary issue with respect to its borders revolved around the borders in the east, that is, towards the Serbs. When it came to the western borders with Italy, the aspirations of the Ustasha government did not extend beyond the Italian Fiume (Rijeka), whereas the Italian Zara (Zadar) was not even mentioned. It should be emphasized that in the autumn of 1943 the Partisan Assembly of Croatia declared the annexation of Istria, Rijeka, Zadar and other parts occupied by Italy to Croatia and Yugoslavia. ${ }^{34}$ The fact that this part of the memorandum was published in the press and the court proceedings in October 1946 and then in the book can be interpreted as the intention of the authorities to show that the National liberation movements of Croatia and Yugoslavia extended the state borders far to the west, while the Ustasha state limited its aspirations only to the Italian Rijeka. In other words, the intention was to show that the true patriots were partisans, not Ustashas.

The position and opinion of the English Government regarding the memorandum of the ISC government and its contents, which was delivered to Foreign Secretary Eden on 18 May 1945, were expressed in comments handwritten on the Memorandum by High Representatives of the Foreign Office. John Addis from the Foreign Office Southern Department made a comment on 18 May 1945: "The signatures of all members of the Croat puppet Govt. On one document will be something of a curiosity for the future historians. There seems to be nothing of interest in the long memorandum" ${ }^{35}$ R. G. D. Laffan of the Foreign Office's Research Department noted on 24 May 1945 that "Croatia may be heard of again some day, but for the present it is finished."

Based on the documents of the Foreign Office, as well as the Yugoslav diplomatic note dated 5 May 1945, it could be concluded that two Ustasha planes departed from Zagreb on the morning of 4 May 1945 and landed at Škabrnje airfield near Zadar, where Yugoslav military authorities took partial control of them. The planes carried three British prisoners of war and Ustasha lieutenant Vitomir Dubaj. On that same day, Allied Force Headquarters and the British Resident Minister in Caserta held in their hands the memorandum in English from the Ustasha government requesting military intervention in the ISC. The British side determined that this was a case of the highest priority and informed the British ambassador

34 The decision of the State Anti-fascist Council for the National Liberation of Croatia (ZAVNOH) on the annexation of Istria, Rijeka, Zadar and other territories occupied by Italy to Croatia, 20 September 1943, Petranović, Zečević 1985: 535--536.

35 Jareb, Omrčanin 1980: 143. 
in Belgrade the same evening. He, in turn, was instructed to brief Marshal Tito on the whole case and assure him that the British side would not conduct any negotiations with the Ustasha representative. Ambassador Stevenson conveyed this to Marshal Tito the following day, who requested in a diplomatic note that the two planes and the Ustasha officer be handed over. Clearly, a dispute arose between the Yugoslav and British sides because the Yugoslav military forces did not have full control over the planes and the Ustasha officer. It was clear to the British that the Yugoslav side had reason to suspect that negotiations between the Ustasha government and Western allies could take place. This is why the British representatives in Caserta and Belgrade reacted so urgently. Two days later, the British side agreed to surrender the two planes and the Ustasha officer, whereas the three British prisoners of war were to be repatriated. It remains unclear how the memorandum arrived from the ISC government to Caserta on 4 May 1945 if the two planes and four crew members tasked with surrendering it had been detained by Yugoslav military forces.

\section{New sources and new dilemmas}

The issue of the ISC government memorandum to the Allied Force Headquarters in Italy along with Vjekoslav Vrančić's mission was investigated by Bogdan Krizman in his large study on the Ustashas and the ISC. ${ }^{36}$ In doing so, he used not only the statement of Mehmed Alajbegović from the 1945 investigation, but also the statements of Vladimir Kren, commander of the ISC Air Force, and Ante Moškov, the organizer of the delivery of the memorandum. Kren and Moškov were extradited to the Yugoslav authorities in 1947 and $1948^{37}$ respectively and in their statements they detailed the circumstances surrounding the creation and the dispatch of the memorandum. Krizman also published a translation into Croatian-Serbian of the text of the memorandum published in the article by J. Jareb and I. Omrčanin. In doing so, he stated that it was the "final redaction" of the memorandum, ${ }^{38}$ i.e., its final version intended for Field Marshal Harold Alexander. It is unclear why Krizman objected the authors omitting a part of, as he called it, the "Croatian version of the memorandum" published in the book Trial of Lisak, Stepinac, Šalic and associates in 1946. This is in reference to the previously quoted passage beginning with "Defense of Croatia" and ending with "to the Adriatic and the Mediterranean". ${ }^{39}$ In other words, if the final wording of the memorandum was published in 1980, then it cannot be said that it lacked something that was, in all likelihood, present in the first edition of the memorandum, partially published in 1946.

One of the concerns regarding the ISC government memorandum is certainly the number of copies of the document. Alajbegovic stated that after adopting the final text of the memorandum, it had been translated into English and "several copies were signed and sealed at the presidency of the government and handed over to General Moškov for dispatch". ${ }^{40}$ This would mean that there were multiple copies of the memorandum, the

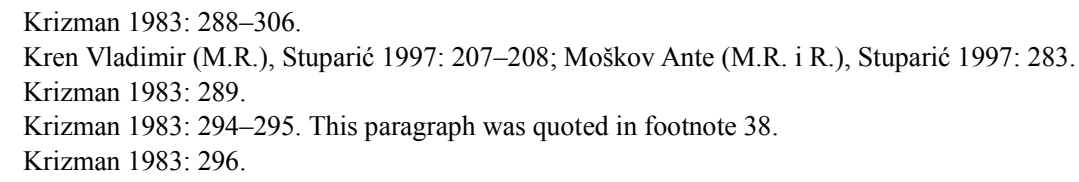


dispatch of which was to be organized by Moškov. Moškov himself stated that someone else had taken the memorandum to Borongaj Airport, where it had arrived as the first plane had been taking off. Somewhat later the second plane had taken off. The first plane carried two English aviators and the second one the Ustasha ensign, an interpreter in a prison camp and an American pilot. "They put the memoranda close to their chest under the uniform". He did not see Vrančić and knew only that Vrančić took off in the direction of Klagenfurt. ${ }^{41}$ Moškov said that the pilots had taken "memoranda" with them. This does not imply that these were multiple copies of the memorandum. He knew that the pilots had taken at least two documents, including the government memorandum, referring to all of them collectively as "memoranda". He stated that he had read part of the memorandum, "and what was relevant in it was the invitation to the Anglo-American armed forces; subsequently, the Russians were also added as having been invited to march in and occupy Croatia". ${ }^{42}$ There are no indications in other sources that the Soviet forces were also invited to intervene in Croatia (ISC). It is hard to believe that the Ustasha government proposed a Soviet occupation, or at least one undertaken jointly with Anglo-Americans, because the tone of the entire memorandum is decidedly anti-Soviet and anti-communist.

That the pilots brought with them "memoranda", or at least two documents, is evidenced by another part of the statement made by A. Moškov. He learned from Minister Edo Bulat that Giovanni Masucci, the secretary of the Papal Legate Marcone, was also supposed to fly to Italy, but that was not possible. "Whether or not the English aviators took with them a coded letter from Legate Marcone to the Vatican and what it contained I do not know and even Bulat could not tell me anything more. It certainly seems to be connected with the Memorandum". ${ }^{43}$ Alajbegović also confirmed this interpretation: "In addition to the memorandum that was sent to the Anglo-Americans, this officer of the CGB [Chief of State's Guard Brigade] carried the memorandum to the Vatican, where he was to deliver it. This was what Moškov told me in Zagreb, after the matter was over". ${ }^{44}$ Based on these sources, it can be concluded that the Allied pilots and the Ustasha officer took with them at least two documents: the memorandum from the ISC government intended for the Allied Force Headquarters in Caserta and an encrypted letter ("memorandum") from the Papal Legate Marcone for the Vatican.

A. Moškov's statement can help resolve some of the concerns related to V. Vrančić's recollections and the diary of G. Masucci. Vrančić stated that on 5 May 1945, in the morning, Prime Minister Mandić had ordered him to prepare to set off on a mission because two US pilots had already taken one copy of the memorandum. The departure of his mission was postponed after Pavelić's telephone call informing him that he was to be joined by the secretary of Abbot Marcone (Masucci) and a Croatian priest. Pavelić subsequently notified him that the priests would not be travelling and at about two o'clock in the afternoon Vrančić departed for Klagenfurt. ${ }^{45}$ On 5 May 1945 Masucci made a note in his diary that he had met Pavelić and that on that same day he was to embark on a special mission with the aim of

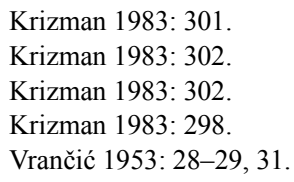


inviting the Allies "to come and occupy Zagreb, where they would not encounter any resistance". He ended the entry by noting that his mission had suddenly been halted at the request of papal Legate Marcone. ${ }^{46}$

It could be concluded that on 5 May 1945 Masucci was supposed to join Vrančić's mission headed towards the Allies via Klagenfurt and northern Italy, but that this plan was abandoned. However, according to Moškov's statement, Masucci was scheduled to depart on a plane with the British pilots to Italy carrying Marcone's encrypted telegram to the Vatican. This could only have taken place on 4 May 1945, when this mission was dispatched and could not be connected with Vrančić's mission. In other words, Masucci's diary entry dated 5 May 1945 can only refer to the mission sent directly to Italy on 4 May, not to one sent via Klagenfurt on 5 May. In that case, Vrančić's description of the departure of his mission would not be credible. That this is indeed the case can be inferred from the statement made by M. Alajbegović. He said that, after the departure of the pilots with the memorandum, they had been waiting for a reply from the Allies; since the answer had not arrived, it had been decided to send one of the ministers to Italy with a memorandum and Pavelić's power of attorney. As three other ministers refused to go, Vrančić agreed to do so and flew to Klagenfurt by plane, from where he continued by car to Italy and the Allies. ${ }^{47}$ This is somewhat different from Moškov's statement that Vrančić volunteered to take the memorandum. ${ }^{48}$ In his statement, Moškov said it had been agreed with the aviators that they would contact them back with a special code, but no response had come, so it had been assumed the planes had crashed or had been shot down by British strike fighters. ${ }^{49}$ In any case, this delayed the start of Vrančić's mission, which allows for the possibility that it began on 5 May, as he himself stated.

According to Moškov's statement, the events were as follows. Towards the end of the war, he learnt from Edo Bulat that a memorandum was being prepared, which should be immediately taken by plane to Anglo-Americans in Italy. Vrančić volunteered for the mission, but Pavelić thought that someone else also had to be sent for security reasons. He thought it best to send one of the captured English or American aviators and, accompanying him, one of the Ustasha military personnel. ${ }^{50}$ According to Kren, in late summer 1944, the Ustasha authorities obtained permission from the Germans to organize a POW camp for the crews of the downed Allied aircraft. The camp was established near Zagreb in the huts on the Nikolić estate. Up until then the ISC authorities had been obliged to hand over all the downed pilots and aircraft material to the German command. ${ }^{51}$ It was a fortunate circumstance for the crews of the downed Allied planes if they were handed over to the German authorities because they would then be sent to the Zemun transient prisoners of war camp (Durchsgangslager 172, Semlin) or to one of the other German POW camps. ${ }^{52}$ The

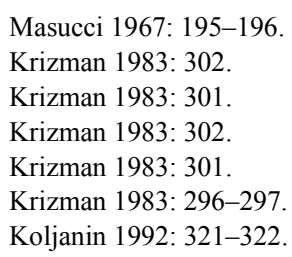


Ustasha units otherwise killed and robbed the downed pilots. ${ }^{53}$

Moškov asked Air Marshals Vladimir Kren and Dragutin Rubčić to go to the prison camp and find pilots who would agree to participate in the mission. ${ }^{54}$ Three pilots volunteered for the mission and were then received by Pavelić. He suggested that they bring with them an Ustasha representative as an interpreter who would enable them to get in touch with the Allied authorities "so that a delegation could be sent to engage in political negotiations". The pilots agreed, upon which it was arranged that they take two small training aircrafts and contact the Ustasha government by radio at a predetermined day and hour. The aircrafts in question were Italian two-seater planes with ISC labels. "In addition to flying equipment, they only asked for a map of the Adriatic Sea. The next morning, they flew away, but never contacted us back". 55

\section{What happened in early May $1945 ?$}

The documents of the Foreign Office and the Yugoslav Government note dated 5 May 1945 show that two planes with ISC insignia landed at the Škabrnje airport the day before. There had been three improvised airports near Zadar since the autumn of 1944 at the locations of Prkos, Škabrnje and Zemunik. In accordance with the agreement between Field Marshal Alexander and Marshal Tito, a British military base (mission) was established in Zadar in late 1944 for the purpose of co-operating with the National Liberation Army forces in the final struggles for the liberation of Yugoslavia. ${ }^{56}$ The airports near Zadar served both the needs of the newly formed Air Force of the National Liberation Army of Yugoslavia and the needs of Anglo-American forces (Balkan Air Force, Royal Air Force and United States Air Force), which operated from airports in Italy. Allied aircrafts damaged during bombing missions over the Balkans and over Germany made emergency landings at the airports near Zadar, as well as at the airport on the island of Vis. The $362^{\text {nd }}$ Squadron (Yugoslav), which also fought as part of the British Air Force, moved from Vis to the area of Prkos-ŠkabrnjeZemunik between February and April 1945. Two British squadrons were also based at Prkos Airport. ${ }^{57}$ Nevertheless, it cannot be argued that Škabrnje was a British Air Force (R.A.F.) airport. ${ }^{58}$ There were both Yugoslav and British air commands at the airport, but it was located, as the British claimed, "on indisputably Yugoslav territory". It was on this basis that Foreign Office subsequently authorized the surrender of the aircrafts to the Yugos lavs. ${ }^{59}$

Despite the publication of documents from British sources, in historiography various interpretations of the dispatch of the ISC government memorandum to the Allied Force Headquarters in Italy were still put forth. According to one of them, on Saturday 5 May

\footnotetext{
53 After the American bomber B24 was shot down on 26 June 1944, the Ustashe captured two American pilots in the area of the village of Kosinjski Bakovac in Lika, killed them and threw them into a pit; Pražić 2019; Mirković 2016: 123.

54 Krizman 1983: 301.

55 Krizman 1983: 297-298, 301-302.

Biber 1981: 404-405, 411.

Shores 1973: 98-103; McConville 1986: 173-179; Jelavić 2003; Pejčić 1977: 162-167.

Jelavić 2003: 120.

Jareb, Omrčanin 1980: 122-123.
} 
1945 a plane operated by two captured US pilots accompanied by two Ustasha officers departed from Zagreb. They carried a memorandum from the Ustasha government for Field Marshal Alexander calling for his army to come to the "free territory of Croatia" and to be "joined by the Croatian armed forces". For security reasons, Minister Vrančić departed on another plane two to three hours later, carrying another copy of the memorandum. ${ }^{60}$ According to this interpretation, a copy of the memorandum carried by two US pilots was already that afternoon in the headquarters of Field Marshal Alexander. In agreement with "the British Minister present at the time", Harold MacMillan, Alexander immediately sent the memorandum to British Ambassador Stevenson in Belgrade, who was to personally hand it over to Marshal Tito on an urgent basis. On the same day, after 6 PM, Ambassador Stevenson, deviating from the usual diplomatic practice, placed the memorandum from the Ustasha government before Marshal Tito. In doing so, Field Marshal Alexander and Minister MacMillan wanted to show that they refused to even consider what was suggested in the memorandum. ${ }^{61}$ Like the previous one, this interpretation also does not concur with the sources. Still, a useful implication of the paper is found in the author's observation that for Tito this was the best evidence that any Ustasha offer to negotiate surrender or collaboration was out of the question for Western allies. ${ }^{62}$

What happened after the two small ISC Air Force training planes took off in the early morning of 4 May 1945 in the direction of Italy, as the government in Zagreb was eagerly waiting for their crews to call back using predetermined signals? From the published British documents it can only partially be concluded what happened after the planes landed at Škabrnje Airport. More details are added based on the report of the Yugoslav military authorities in Škabrnje airport dated 4 May 1945, which was forwarded by the Ministry of National Defense to the Ministry of Foreign Affairs of Yugoslavia. ${ }^{63}$ Since this report is for several reasons very valuable, here it is given in extenso.

“Today, on 4 May, two Saimon planes arrived from Zagreb to Škabrnje Airport near Zadar. In the first plane, which landed at 07.30 hours, there were British pilots:

P/o Woods R. J. A. 181184

P/o Gray H. B. 191341

In the second plane, which landed at 09.00 hours, there were an American pilot:

L /-lt Benkoski E. F. 0715444 (of Polish descent), and Ustasha ensign Dubaj Vitomir adjutant from the prison camp No.1 in Zagreb.

After they landed, Captain Gledja Mile, OZNA ${ }^{64}$ Officer for Zemunik Airport, was requested to extradite the aforementioned four to our authorities. The British, headed by the commander of the British Mission in Zadar, under the rank of Air Commodore (name unknown), did not agree to this; all four of them, until further instructions from our and British authorities, are under watch by our and British guards.

At 11.00 hours the interrogation of these four men was commenced by the British and our authorities. During the first brief hearing the following was established:

60 Ivin 2007: 44. Not only is the departure of the mission wrong here, but some of the paragraphs cited as parts of the memorandum, were not published either in the 1946 edition, or in the English version published in 1980.

61 Ivin 2007: 45.

62 Ibid.

63 DA MSP, PA, 1945, f-19/3.

64 OZNA, Department for People's protection, Yugoslav security service 
Both British and American pilots were summoned by the Ustasha General Kren and then by Pavelić himself. They both offered them to make contact with the Allied Force Headquarters in the Mediterranean. They accepted this offer. They brought with them a large envelope weighing roughly 200 grams, sealed with a large Croatian coat of arms. It is addressed to the "Allied General Staff for the Mediterranean".

The other two brought with them two letters that the Ustasha General Rupčić had handed over to ensign Dubaj. The first letter is addressed to the Spanish Embassy in Rome and the second to the Vatican. According to Dubaj, both letters were sent by Archbishop Stepinac.

The letter addressed to the Allied Force Headquarters in the Mediterranean was taken by $\mathrm{Gr} / \mathrm{Cpt}$ Boyde by plane to Italy. He departed at 11.30 hours.

The other two letters were handed over to Captain Gledja for safekeeping, as we are waiting for further instructions from our and British authorities about what to do with them. We attach both letters.

Allied pilots promised Pavelić that, if possible, one of them would return to Zagreb and bring an answer. They gave their word of honour. It was jointly decided that no one was to be sent to Zagreb until instructions from higher authorities arrived.

Attached is some literature found on the other plane. In addition to this, a batch of 5,000 cigarettes addressed to General Moškov was also discovered in the plane.

Death to fascism - freedom to the people!

Škabrnje, 4 May 1945"

The report stated that enclosed were two letters sent by Archbishop Stepinac, but they were not attached to the document and it is not known where they were archived. Together with the report dated 4 May 1945, there are three other documents in the same case file. The first of these is the note of the Ministry of Foreign Affairs of Yugoslavia dated 5 May 1945, which Marshal Tito delivered to British Ambassador Stevenson on his visit in the afternoon of the same day. The note was submitted in two versions: Serbo-Croatian and English. ${ }^{65}$ The next document is a response from the British Embassy in Belgrade to the Yugoslav Ministry of Foreign Affairs on 9 May 1945. It stated "that two German aircrafts which landed at Škabrnje airodrome carrying a document signed by members of the Croat Government, will be handed over to the Yugoslav military authorities together with the Croat officer who accompanied them". ${ }^{66}$ The last document in the case file is a letter from Colonel Brilej, Assistant to the Political Chief in the Ministry of Foreign Affairs, addressed to the Ministry of National Defense on 11 May 1945. It contains the answer of the British Embassy of May 91945 regarding the surrender of the two planes and the "Ustasha officer" to Yugoslav military authorities. ${ }^{67}$

These documents show that on the morning of May 4 1945, at 7.30 and at 9.00, two Ustasha aircrafts with three Allied pilots, prisoners of war and one Ustasha ensign landed at Škabrnje airport. Thereafter, a matter of disagreement arose between Yugoslav and British

65 DA MFA, PA, 1945, f-19/4-5, Nr. 819. The note was published in English in Jareb, Omrčanin in 1980, and in Serbo-Croatian in D. Biber in 1981. The Serbo-Croatian text indicates that Dubaj's rank was ensign, whereas in the English text he is referred to as Second Lieutenant. Thus, he was also referred to as Second Lieutenant in Stevenson's telegram to MacMillan on 5 May 1945; Jareb, Omrčanin 1980: 121. Moškov, however, confirmed that Dubaj had the rank of ensign.

66 DA MFA, PA, 1945, f-19/6, British Embassy Belgrade, No.62, 9 May 1945.

67 DA MFA, PA, 1945, f-19/7, Ministry of Foreign Affairs, Political Departments, to the Ministry of National Defense, No. 877, Belgrade, 11 May 1945. 
military representatives. The captain of the Yugoslav security service demanded that all four be handed over to the Yugoslav authorities, which the British side refused. The British side was represented by a high-ranking mission commander in Zadar (Air Commodore) ${ }^{68}$ It was finally agreed that all four would be under common guard until both parties received instructions from their respective superiors. At 11.00, the first joint interrogation by Yugoslav and British officers began. The three pilots stated that they had been offered by General Kren, and later by Pavelić himself, to establish a connection with the Allied command in the Mediterranean, which they had accepted. The first two brought with them a large sealed envelope addressed to the Allied Force Headquarters for the Mediterranean. The other two carried two letters from Archbishop Stepinac addressed to the Spanish mission in Rome and to the Vatican. The pilots promised Pavelic that at least one of them would return to Zagreb with an answer. Both the British and the Yugoslav side agreed to wait for instructions from their superiors.

However, half an hour after the hearing began, at 11.30, British captain Boyd flew to Italy with the letter to the Allied Force Headquarters. It is possible that in the meantime the British in Škabrnje or Zadar were instructed by the Mediterranean command to deliver the document that had been sent. According to the second more likely, assumption, the British sent the document to Italy on their own initiative. In any case, this was a great surprise to the Yugoslav side, who did not know at whose orders Captain Boyd departed for Italy with the Ustasha government document addressed to Allied Force Headquarters. The letters sent by Archbishop Stepinac took a different route. According to the agreement, letters were handed over to Captain Gledja from OZNA, with a provision to wait for further instructions from the Yugoslav and British authorities. However, without instructions from Belgrade, the letters were attached to the report and sent to Belgrade. This may have been the response of the Yugoslav side to the fact that the document addressed to the Allied command had been taken to Italy without an explanation from the British side. In any case, there are no indications that the British had any objections to the dispatch of the two letters sent by Archbishop Stepinac, nor are they mentioned in British documents.

Based on the report of 4 May 1945, it is clear why British diplomatic and military representatives in Italy reacted the same day. It was clear to them that the Yugoslav side knew that a document from the Ustasha government from Zagreb requesting contact with Allied command had arrived in Caserta and they assumed that it would cause great suspicion in Belgrade. Ambassador MacMillan, therefore, ordered Ambassador Stevenson in Belgrade to request a meeting with the Yugoslav Prime Minister Marshal Tito on the same evening in order to explain what had happened and to convey to him that the British side had rejected the possibility of any negotiations. ${ }^{69}$ During the conversation with Marshal Tito on 5 May 1945, it was necessary to assure Belgrade that there were no clandestine dealings with the Ustasha government. Ambassador Stevenson conveyed to Marshal Tito the circumstances of the entire event and made available to him a list of signatories to the

68 Jelavić 2003: 165. The type of the planes which landed at Škabrnje is incorrectly stated in this reference, including some other erroneous claims with respect to the mission; Jelavić 2003: 120. See also: Mikić 2000: 174.

69 Probably due to the urgency, McMillan stated in his telegram to Ambassador Stevenson that a German plane had landed at the airport near Zadar; Jareb, Omrčanin 1980: 124. 
memorandum, with which the Yugoslav Prime Minister was satisfied. The Yugoslav side also placed the highest importance to this matter, which is evident from the fact that the note was delivered to the British ambassador by Marshal Tito himself, the President of the Council of Ministers and the Minister of National Defense, not the Minister of Foreign Affairs Dr. Ivan Šubašić.

According to the note, the Yugoslav government required only the surrender of the two aircrafts and the Ustasha second lieutenant, who was referred to as a "rebel". The request was granted on 9 May 1945 and the case was concluded to the satisfaction of both parties. Although British pilots had promised that one of them would return to Zagreb with the Allies' response following Ambassador MacMillan's instructions given on 7 May 1945, the pilots were absolved from their promise ${ }^{70}$ and the issue was settled in accordance with the demands of the Yugoslav side. The question remains why the two planes landed at the airport near Zadar. It is logical to assume that the captured pilots knew that the Allied aircraft landed at the airport, that the British were stationed there and that attempting to fly across the Adriatic on two small ISC-labelled aircraft would be too risky.

The efforts of the British to determine whether the airport in Škabrnje was located in a territory that was indisputably Yugoslav or in an Italian territory to which the Yugoslavs made claims pointed to a much larger problem. In late April and early May 1945 the Yugoslav Army occupied large parts of the Italian state territory (Istria, Trieste and Julian March). This led to a gradual tightening of relations between the British and Yugoslav armies ${ }^{71}$ and had the potential to turn into an armed conflict. This was repeated in the second half of May 1945, when the Yugoslavs occupied parts of southern Austria. As the British felt that the Yugoslav side did not respect the reached agreements, on 2 May 1945 they decided to suspend military deliveries to the Yugoslavs. ${ }^{72}$

With respect to the attitude toward the anti-partisan forces in Yugoslavia and their possible offer of co-operation, the British took a principled stance at the end of April 1945. Based on the assessment of Ambassador Stevenson in Belgrade, they decided not to accept any negotiations with anti-partisan forces concentrated in Slovenia. They were to be disarmed and placed in refugee camps. According to a telegram from the Foreign Office sent to Washington on 30 April 1945, there could be no justification "for cooperating with these troops, which have so far openly collaborated with the Germans. These troops are likely to consist of Croatian Ustashas and Slovene White Guards". ${ }^{73}$ The refusal to take part in any negotiations with the Ustashe, of which Marshal Tito was urgently notified on 5 May 1945, and the extradition of the Ustashas ensign Dubaj to the Yugoslav authorities were a confirmation of this principled position. It remained in effect even after the formal end of the war on 9 May 1945. On 15 May 1945 the British command in southern Austria refused to negotiate with the ISC representatives on the surrender of a large group of Ustasha military forces, together with whom other antipartisan forces and numerous civilians were retreating. They were handed over to the Yugoslav Army, which was followed by mass extrajudicial executions. ${ }^{74}$

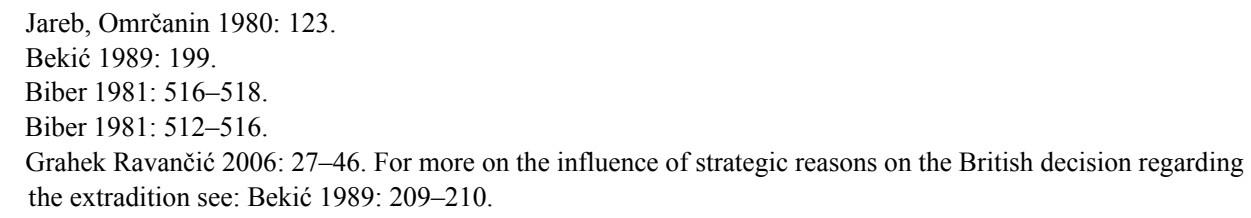




\section{The Archbishop and the state policy}

The existence of the memorandum from the ISC government addressed to the Allied Force Headquarters in Italy in early May 1945 became known to the public during the trial of Archbishop Stepinac and others in October 1946. From everything put forth during the trial, as well as from the information given in the book after the trial, it is possible to conclude that on the eve of the collapse, the Ustasha government tried to contact the Allied Force Headquarters in Italy by calling for their military intervention in order to preserve the ISC. The hopes of the Ustasha leadership were tied to the expected conflict between Western Allies and the Soviet Union, based on the belief in their irreconcilable ideological differences. The Ustasha government offered to make their state part of a future anti-Bolshevik bloc along with Albania, Greece and Turkey. Interestingly, the memorandum did not imply any possible military action against German forces in the ISC, which would constitute a real help to the Allies in ending the war. Instead, the ISC leadership counted on a new war and a new military and political constellation in which a large independent Croatian state, as part of the imagined anti-Bolshevik Antemurale Christianitatis, would have its place.

It should be noted that the argumentation presented in the memorandum of the ISC government was essentially the same as that presented in the epistle of the Episcopal Conference chaired by Archbishop Stepinac, which took place at the end of March 1945. It emphasized the need to prevent the victory of ungodly communism and the defeat of the Independent State of Croatia. The epistle was primarily aimed at Western powers and the Vatican, which is why it was translated into foreign languages and broadcast over the radio, especially aimed at North American listeners. ${ }^{75}$

In considering the role of Archbishop Stepinac during the last days of the existence of the ISC, the diary of G. Masucci, Secretary of the Holy See Legate G. R. Marcone should once again be examined. Masucci noted on 2 May 1945 that he had spoken to Stepinac, who was "probably going to travel to Rome. Tomorrow everything will be decided with Poglavnik" ${ }^{76}$ Subsequent developments indicate that this was probably related to the ISC government's planned action to establish links with Western allies. The next day Masucci noted that he met with Pavelić, with whom he had discussed "ways of reaching an agreement with the English by inviting them to come to Zagreb and thus preventing communist occupation". ${ }^{77}$ According to the entry dated 5 May 1945, Masucci again met with Pavelić. He noted that he was supposed to embark on a special mission that day in order to invite the Allies "to come and occupy Zagreb, where they would not encounter any resistance". He ended the entry by noting that his mission was suddenly halted at the request of Papal Legate Marcone. ${ }^{78}$ Since, according to the statement of Ante Moškov from 1947, Masucci was supposed to depart on a plane to Italy with the British pilots carrying Marcone's encrypted telegram to the Vatican, this could only have taken place on 4 May 1945, when the mission with the memorandum was sent directly to Italy.

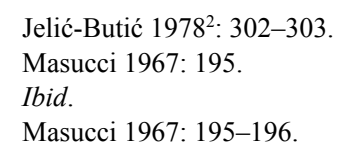


The fact that the Croatian officer carried the memorandum for the Vatican where he was supposed to deliver it is further confirmed by Alajbegović. Unlike Moškov, he did not state that the telegram had been from Marcone, but only that it should have been handed over to the Vatican. This fits in with the picture that was formed on the basis of the report of the Yugoslav military command from Škabrnje of 5 May 1945.

The pilots who landed in Škabrnje on 4 May 1945 carried, in addition to the ISC government memorandum for the Allied Force Headquarters, two more letters; however, the letters were not sent by Abbot Marcone. The letters carried by the Ustasha ensign Dubaj and the American pilot Lieutenant Benkoski were sent by Archbishop Stepinac, one intended for the Vatican and the other for the Spanish embassy in Rome. According to a statement from Dubaj, the letters had been given to him by Ustasha General Rubčić, one of the organizers of the memorandum's dispatch. Since these letters are not available to researchers, we can only speculate as to their content. Nevertheless, the letters were certainly linked to the dispatch of the memorandum, especially the letter to the Vatican, as it cannot be a coincidence that all these documents were sent to Italy on a single mission. It can be assumed that Archbishop Stepinac expected the Holy See to support the efforts of the Ustasha government in establishing links with Western allies. In any case, it is difficult to accept Archbishop Stepinac's statement at the October 1946 trial that he had not been told that any connection was to be made with the Allies, that the aviators had left with the memorandum and that he was not aware of its contents. It remains open for speculation why the Archbishop also sent a letter to the Spanish embassy in Rome.

The aforementioned activities of Archbishop Stepinac should be seen as his final attempt to preserve the great Croatian state, for which he wholeheartedly advocated since its proclamation. However, in 1943 it became clear to him that the policies of the Ustasha government did not contribute to the prosperity of the Independent State of Croatia and, consequently, the Catholic Church within it. ${ }^{79}$ The archbishop made contacts with Western allies and with the Yugoslav Government in exile by various means and channels, ${ }^{80}$ but this did not lead to any kind of political action. The archbishop remained loyal to the Ustasha state and its leader until the very end.

Stepinac's expectations placed on the Holy See were in line with the Vatican's policy of preserving the ISC as an independent state and turning it into an ally of the Western powers. ${ }^{81}$ Assuming this was the contents of Archbishop Stepinac's letter, the question that arises is why the letter was not used as evidence against him in the 1946 trial. It is possible that, as the trial was being prepared, the Yugoslav authorities concluded that there was no need to further tighten relations with Western powers, which were already quite bad at the time. It is also possible that the letters were encrypted and that the police could not decipher them. In any case, by sending the letters to the Vatican and Rome, Archbishop Stepinac found himself once again, in his own way, on the political scene. At the time of the events, the archbishop was also given an eminently political role. Pavelić offered him to take over power, which he did not accept. Stepinac suggested that Vlatko Maček should take this position,

\footnotetext{
Živojinović 1994: 66-67.

Boban 1985: passim.

Živojinović 1994: 61, 95, 107.
} 
considering that he, as a political leader, was more suitable. Here, the Archbishop acted as a highly politically engaged person, again in his own way. In doing so, Stepinac's actions were part of an effort to bring about a change in the leadership of the ISC government, which would be headed by a person acceptable to Western Allies. All this happened just before the collapse of the Ustasha state and the departure of its leadership from Zagreb.

The memorandum from the ISC government together with, in all likelihood, Stepinac's letter to the Holy See, reflect the ISC's hopes of a conflict between Western allies and the Soviet Union and a radical change in international relations. Zagreb expected that a decisive role would be played by a foreign factor, as it had been the case during the creation of the state. This time, it was expected that, instead of the Nazi and Fascist powers, the preservation of such a state would be made possible by democratic countries against whose allies the Ustasha state had waged war both outside the country and within it. Unlike the other allies of Nazi Germany, it was immediately prior to Germany's capitulation that the Ustasha government tried to cross over to the side of the victors. This was only to a lesser extent the result of poor political judgment. The comprehensive and deep connection between the Nazi and Ustasha states stemmed from their intrinsic ideological and political likeness. No matter how inevitable the clash between Western allies and the Soviet Union seemed, it was completely unrealistic that this should happen for the sake of the defense of "Hitler's last ally". Along with the leadership of the Ustasha state, this illusion was shared by Archbishop Stepinac.

\section{REFERENCES:}

SOURCES:

Diplomatic Archive of the Ministry of Foreign Affairs of the Republic of Serbia, Belgrade, Political Archive, 1945, f-19/3, f/19/4-5, f-19/6 (referred to in the text as DA MFA, PA, 1945) [Diplomatski arhiv Ministarstva spoljnih poslova Republike Srbije, Beograd, Politička arhiva, 1945, f-19/3, f-19/4-5, f-19/6, f-19/7 (abbr.: DA MSP, PA, 1945)]

\section{REFERENCES:}

Basta, M. Agonija i slom Nezavisne Države Hrvatske, Beograd: IRO Rad, 1971.

Bekić, D. 'Slučaj Bleiburg': Nova istraživanja, nova iskušenja', Časopis za suvremenu povijest, 21 (1-3), 1989, 197-214.

Biber, D. (prir.), Tito-Churchill strogo tajno, Beograd, Zagreb: Arhiv Jugoslavije, Globus, 1981.

Boban, Lj. Hrvatska u arhivima izbjegličke vlade 1941-1943. Izvještaji informatora o prilikama u Hrvatskoj, Zagreb: Globus, 1985.

Grahek Ravančić, M. "Controversies about the Croatian victims at Bleiburg and 'Death marches", Review of Croatian history, II (1), 2006, 27-46.

Ivin, D. 'Smisao Bleiburga', Bleiburg i Križni put 1945. Zbornik radova sa znanstvenog skupa, Zagreb 12. Travnja 2006, Zagreb: Savez antifašističkih boraca i antifašista Republike Hrvatske, Multigraf marketing, 2007.

Jareb, J. Omrčanin, I. 'Croatian Government's Memorandum to the Allied Headquarters Mediterranean, May 4, 1945', Journal of Croatian Studies, XXI, 1980, 120-143.

Jelavić, T. No. 362 (Y) R.A.F. Squadron, Nova Gradška: Danko Čanak, 2003. 
Jelić-Butić, F. Ustaše i Nezavisna Država Hrvatska 1941-1945, Zagreb: SN Liber, Školska knjiga, $1978^{2}$

Koljanin, M. Nemački logor na Beogradskom sajmištu 1941-1944, Beograd: Institut za savremenu istoriju, 1992.

Krizman, B. Ustaše i Treći Reich, knjiga 2, Zagreb: Globus, 1983.

Masucci, G. Misija u Hrvatskoj, Madrid: Editorial 'Drina', 1967.

McAdams, Ch. M. Allied War Prisoners of War in Croatia 1941-1945, Arcadia CA: Croatian Information Service, 1980.

McConville, M. A Small War in the Balkans. British Military Involvement in Wartime Yugoslavia, 1941-1945, London: Macmillan, 1986.

Mikić, V. M. Vazduhoplovstvo Nezavisne Države Hrvatske 1941-1945. Godine, Beograd: Vojnoistorijski institut Vojske Jugoslavije, Target, 2000.

Mirković, J. Stradanje Srpske pravoslavne crkve u Nezavisnoj Državi Hrvatskoj. Fotomonografija, Beograd: Svet knjige, 2016. (Serbian Cyrillic)

Pejčić, P. ‘Aerodrom na Visu', Čuvari našeg neba, Beograd: Komanda Ratnog vazduhoplovstva i protivvazdušne odbrane, 1977.

Petranović, B. Zečević, M. Jugoslavija 1918-1984. Zbirka dokumenata, Beograd: IRO Rad, 1985.

Pražić, Đ. 'Ubistvo američkih vazduhoplovaca u Kosinjskom Bakovcu (Lika) 1944.godine', www.gospic.rs (accessed 6 June 2019) (Serbian Cyrillic)

Shores, Ch. F. Pictorial History of the Mediterranean Air War, Vol. II: RAF 1943-45, London: Ian Allan, 1973.

Stanić, M. (ur.), Suđenje Lisaku, Stepincu, Šaliću i družini, ustaško-križarskim zločincima i njihovim pomagačima, Zagreb: izdanje autora, 1946.

Stuparić. D (ur.). Tko je tko u NDH: Hrvatska 1941.-1945, Zagreb: Minerva, 1997.

Vrančić, V. S bielom zastavom preko Alpa. U misiji hrvatske državne vlade za predaju hrvatskih oružanih snaga, Buenos Aires: Hrvatska pučka knjižnica, 1953.

Živojinović, D. Vatikan, Katolička crkva i jugoslovenska vlast 1941-1958, Beograd: Prosveta, Tarsit, 1994. (Serbian Cyrillic)

\section{МИЛАН КОљАНИН}

Институт за савремену историју, Београд

ДРАГИЦА КОљАНИН

Универзитет у Новом Саду, Филозофски факултет

Одсек за историју

\section{НАДБИСКУП СТЕПИНАЦ, НДХ И ЗАПАДНИ САВЕЗНИЦИ}

\section{Резиме}

Пред сам крај Другог светског рата врх усташке државе је покушао да води политичке преговоре са западним савезницима ради њеног спасавања рачунајући на њихов сукоб са комунистичким Совјетским Савезом. У својим намерама усташка влада је имала подршку представника Свете Столице у Загребу и надбискупа Степинца. Намере усташке владе су изражене у меморандуму упућеном генералштабу савезничких снага на Средоземљу у Италији 
(Казерта) у којем се тражила њихова војна интервенција. Меморандум је преведен на енглески језик и 4. маја 1945, су два примерка упућен у Казерту. Један примерак је, уз помоћ немачког посланика у Загребу, носио министар Вјекослав Вранчић заобилазно преко Аустрије и северне Италије, али су га ухапсиле британске власти. Други примерак меморандума је упућен најкраћим путем у Италију и стигао је у савезничку команду у Казерти, али не директно. Та мисија је, уз меморандум, носила и два писма надбискупа Степинца, за Ватикан и шпанско посланство у Риму. Обзиром да је сва ова документа носила иста мисија, највероватније је Степинчево писмо подупирало молбу владе НДХ западним савезницима да изврше војну интервенцију и омогуће њен опстанак. Усташка мисија је слетела на аеродром Шкабрње крај Задра где су биле и југословенска и британска ваздухопловна команда међу којима је у вези хапшења чланова мисије дошло до спора. Без знања југословенске команде меморандум је упућен у Казерту што се већ истог дана сазнало у Београду. Спор је изглађен наредног дана између британског амбасадора у Београду и председника југословенске владе. Југословенска страна је добила уверавања да неће бити никаквих преговора са усташама и да ће два авиона и усташки подофицир бити изручени југословенским војним властима, што је убрзо испуњено. Крајем априла 1945. Британија је усвојила начело да неће бити никавих преговора са антипартизанским снагама у Југославији, а да ће они који се предају бити упућени у заробљеничке логоре. У првој половини маја 1945.односи нове југословенске владе и западних савезника били су све заоштренији јер је Југословенска армија запосела велике делове италијанске територије (Истра, Јулијска крајина, Трст), што се у другој половини маја 1945. поновило због запоседања јужне Аустрије. И поред тога, Британци су својим југословенски савезницима предали десетине хиљада припадника војске НДХ и других антипартизанских снага, од којих су многи страдали у масовним вансудским егзекуцијама. Током последњих дана НДХ надбискуп Степинац имао је изразито политичку улогу. Својим писмом Светој Столици он је највероватније подупирао молбу усташке владе савезницима да војно интервенишу. Истовремено, он је био главни посредник у покушају преноса власти са Павелића на Влатка Мачека за којег се веровало да је прихватљив западним савезницима. Ма колико је изгледало да ће неминовно доћи до сукоба западних савезника и Совјетског Савеза, било је потпуно нестварно да се то догоди ради одбране државе „Хитлеровог последњег савезника“. Заједно са вођством усташке државе, ту илузију је делио и надбискуп Степинац.

Кључне речи: Други светски рат, Југославије, усташка влада, меморандум, западни савезници, надбискуп Степинац, Света Столица. 